\title{
Genetic polymorphisms and their involvement in the regulation of the inflammatory response in asthma and COPD
}

\author{
Juan M. Reséndiz-Hernández ${ }^{1,2, A-D}$, Ramcés Falfán-Valencia ${ }^{1, A-F}$ \\ ${ }^{1}$ HLA Laboratory, National Institute of Respiratory Diseases Ismael Cosio Villegas, Mexico City, Mexico \\ ${ }^{2}$ Graduate Program in Biological Sciences, National Autonomous University of Mexico, Mexico City, Mexico \\ A - research concept and design; $\mathrm{B}$ - collection and/or assembly of data; $\mathrm{C}$ - data analysis and interpretation; \\ $D$ - writing the article; $E$ - critical revision of the article; $F$ - final approval of the article
}

Address for correspondence

Ramcés Falfán-Valencia

E-mail:dcb_rfalfanv@hotmail.com

\section{Funding sources}

Juan M. Reséndiz-Hernández obtained a scholarship from CONACyT, Mexico, No. 233765, and Ramcés Falfán-Valencia obtained a grant from the Fondo Sectorial de Investigación en Salud y Seguridad Social (FOSIS) from CONACyT, Mexico, project: SALUD-2008-C01-87380.

Conflict of interest

None declared

Received on March 8, 2016

Reviewed on May 16, 2016

Accepted on 0ctober 6, 2016

\begin{abstract}
Asthma and chronic obstructive pulmonary disease (COPD) are widely documented diseases with an inflammatory component. Asthma is a heterogeneous disorder of the airways that involves chronic inflammation, decline of the airway function and tissue remodeling. Chronic obstructive pulmonary disease is a preventable and treatable disease, which is characterized by persistent limited airflow, and is usually progressive with an increased inflammatory response in the airways. The inflammatory response is evoked by the stimulus of noxious particles and gases. Inflammation is a natural process in response to injury, but in asthma and COPD patients it occurs as an abnormal immune response to pathogenic stimuli which induce chronic inflammation, a key process in the pathogenesis of both diseases. However, the inflammatory process is different in both diseases, and is involved in several release patterns of inflammation mediators. It is not entirely clear whether these proteins are simply markers of the inflammatory process that accompanies a chronic disease or if they play a major role in the pathogenesis of the disease. The main proteins which have been described in these illnesses are: IL-4, IL-6, IL-8, and TNF-a. In addition, polymorphisms have been described in genes encoding these proteins that alter the transcription and susceptibility associated with these diseases. In this review, we will focus on asthma and COPD, and the involvement of these proteins and their genetic polymorphisms.
\end{abstract}

Key words: asthma, COPD, gene regulation, SNP, TNF-a

DOI

$10.17219 /$ acem/65691

\section{Copyright}

Copyright by Author(s)

This is an article distributed under the terms of the

Creative Commons Attribution Non-Commercial License

(http://creativecommons.org/licenses/by-nc-nd/4.0/) 


\section{Background}

Inflammation is a common process in chronic respiratory diseases. The presence of increased levels of systemic inflammatory markers is a recurrent finding in laboratory tests. In particular, asthma and chronic obstructive pulmonary disease (COPD) are diseases with a widely documented inflammatory component and have been discussed in various studies; however, given the transversal nature of most of the studies conducted so far and the possible confusion regarding a number of external factors related to lifestyle associated with levels of inflammatory biomarkers, which in turn, are generally nonspecific, it is not entirely clear whether these proteins are simply markers of the inflammatory process that accompanies a chronic disease or if they play a major role in the pathogenesis of the disease. In this review, we will focus on asthma and COPD as study models.

\section{Asthma}

Asthma is a heterogeneous disorder of the airways that involves chronic inflammation, decline of the airway function and tissue remodeling. ${ }^{1}$ The overall prevalence varies between $1 \%$ and $18 \%$ of the population in different latitudes. ${ }^{2}$ In developed countries, asthma is found in about $10 \%$ of adults, while in emerging countries, the prevalence is lower, but rapidly increasing, most likely due to underdiagnosis. The World Health Organization (WHO) estimates that 300 million people worldwide are affected by the disorder and this number is estimated to increase to 400 million by $2025 .^{3}$ Although there are no specific genetic or environmental factors conclusive, genetic predisposition to increased immunoglobulin $\mathrm{E}$ (IgE) in local mucosa (atopy) is a strong risk factor for developing the disease. ${ }^{4,5}$ It has been proposed that asthma develops from a complex interplay between genetic and environmental factors, such as the dose of allergens and respiratory tract infections. ${ }^{4}$ This culminates with an abnormal inflammatory response directed by Th2 cells to normally innocuous allergen content in the air. ${ }^{6}$

\section{Chronic asthma immunopathogenesis}

Inflammation is a natural process in response to injury, but it occurs in asthmatic patients as an abnormal immune response to pathogenic stimuli which induces chronic inflammation, a key process in the pathogenesis of the disease. ${ }^{7}$ Another crucial event in the development of asthma is the recruitment of leukocytes mediated by chemokines, which produce an inappropriate immune activation, believed to be in part responsible for the chronic allergic asthma. ${ }^{8}$ In chronic asthma there is an accumulation of CD4 + T cells in airway. ${ }^{9}$ These cells typically exhibit an immune response called Th2 cytokine profile characterized by the production of interleukins (IL): IL-4, IL-5 and IL-13, which contribute to the recruitment of eosinophils and the development of airway hyperresponsiveness. ${ }^{10-12}$ Moreover, in recent years research has suggested the involvement of Th17 cells, which secrete IL-17A, believed to contribute to the pathogenesis of the disease, however, its mechanism remains obscure. ${ }^{13}$ The initiation of the allergic response in the airways begins with epithelial cells, which release thymic stromal lymphopoietin (TSLP), IL-33 and IL-25 in response to allergens. TSLP regulate the migration of dendritic cells (DCs), present antigen and promote Th cell differentiation. Th cells mediate the IgE isotype switching in B cells. The antigen-specific IgE response leads to the recruitment of mast cells and basophils into the airways, increasing the local allergic response. Additionally, IL-33 and IL-25 induce the release of IL-13 and IL- 5 from CD25 + Th cells into the airway, which promotes Th2 cells differentiation and local production of cytokines, such as IL-4, IL-5 and IL-13. ${ }^{14}$ In this process, B-cells and memory $\mathrm{T}$ cells are generated, which facilitates a faster response to repeated stimulation, thereby causing the chronicity of the disease. ${ }^{15}$ Knowledge of asthma molecular phenotypes and the molecular pathways involved in asthma, in particular cytokines which are involved in them, has allowed us to create subgroups of asthma patients based on the activity (or inactivity) of specific cytokine pathways. There have been several studies of gene expression based on the fact that epithelial cells respond to stimuli of various cytokines and they found various overexpressed genes. The calciumactivated chloride channel accessory 1 (CLCA1), periostin (POSTN), serpine peptidase inhibitor (SERPINB3), are all involved in the regulation of IL-13 and IL-4, and therefore Th2 inflammation. ${ }^{16,17}$ Other genes that have been found over-expressed in asthmatic patients are ACACA, TPSAB1 and proteins which are secreted by mast cells. These cells have been implicated in airway hyperresponsiveness, although it has been reported that this is a variable in asthmatic patients. ${ }^{18,19}$ The stimulation of bronchial epithelial cells with IL-13 induces the expression of stem cell factor, which is a growth factor and a mast cell attractant. This induction of stem cell factor provides a mechanism for increasing the number of intraepithelial mast cells, which are of particular importance in severe asthma. ${ }^{20}$ Genetic polymorphisms in asthma/asthma-like diseases may increase the risk for developing these diseases that are determined by environmental factors. In fact, twin studies have estimated heritability ranging from $35-90 \% .{ }^{21}$ Different genome-wide association studies (GWAS) have found different genes related to the development and phenotypic features of the disease, as ORMDL3 (ORM1-like 3), PDE4D (phosphodiesterase 4D, cAMP-specific), $I L-1 R L 1$ (interleukin-1 receptor-like 1), $I L-18 R 1$ (interleukin-18 receptor 1), HLA-DQ, IL33, SMAD3 (SMAD family member 3), and $I L-2 R B$ (interleukin-2 receptor beta). ${ }^{22-24}$ Moreover, through genetic association studies and family-based 
information, in certain specific protein coding genes it was identified that single nucleotide polymorphisms (SNP) are related to the development of asthma or phenotypes responding to treatment differently. Among thes, human leukocyte antigen (HLA), T-cell receptor (TCR), and cytotoxic T-lymphocyte-associated antigen (CTLA-4) may be mentioned. Additionally, genetic variations have been found in genes that encode proteins involved in the inflammatory process, as IL-4, -9, -13, and their respective receptors and intracellular signaling molecules, such as signal transducer and activator of transcription (STAT-6), suppressor of cytokine signaling (SOCS-1). ${ }^{26}$ Although many of these findings have been replicated in other populations, some of the studies failed to replicate the same results. This is of vital importance because the studies replicate different polymorphisms (within the same chromosome) forming haplotypes and how they contribute to or elucidate a set of genes that may be involved in the development and the progression of the disease.

\section{Chronic obstructive pulmonary disease}

Chronic obstructive pulmonary disease (COPD) is defined by the Global Initiative for Obstructive Lung Disease (GOLD) as a preventable and treatable disease, which is characterized by persistent limited airflow, which is usually progressive with an increased inflammatory response in the airways, the response is to the stimulus of particles and gases. Exacerbations and co-morbidities contribute to the individual illness severity (GOLD 2011). Cigarette smoking is the major environmental risk factor for developing COPD in emerging countries like Nepal, Colombia and Mexico and is also associated with exposure to wood smoke. ${ }^{28,29}$ The worldwide prevalence of COPD ranges between $5 \%$ and $10 \%$ (it has increased in recent decades) and is more common in men than in women in the case of exposure to cigarette smoke. The Latin American Project for the Investigation of Obstructive Lung Disease (PLATINO) obstructive pulmonary research, conducted by the Latin American Thoracic Association (ALAT), determined the prevalence of COPD in 5 Latin American countries and found that the percentages vary between countries from $7.8 \%$ in Mexico City to $17 \%$ in Montevideo. ${ }^{30}$

\section{Inflammation in COPD}

COPD is a condition characterized by inflammation and airway remodeling, as well as inflammation and the destruction of lung parenchyma, resulting in the obstruction of expiratory airflow, lung hyperinflation retractability, loss of elasticity, and finally altered gas exchange. Lung remodeling and tissue damage coupled with wall thickening, inflammation and fibrosis of the small airways seem to play an important role in the pathogenesis of COPD. ${ }^{31}$
Pulmonary parenchymal inflammation, oxidative stress, apoptosis, and proteolysis eventually result in emphysematous destruction of the alveolar wall. ${ }^{32}$

\section{Inflammatory mediators involved in COPD}

The family of proteins known as chemokines and chemokine receptors is considered to be key mediators in inflammatory cell recruitment. Chemokine receptors play an important role in the trafficking of immune cells to sites of injury and inflammation after an antigen encounter. Approximately, 50 chemokines and their 20 receptors have been associated with COPD. Among its functions is the ability to drive the migration of leukocytes involved in proliferation, differentiation, survival, and cellular retention. ${ }^{33}$ In addition, chemokine receptors 5 (CCR5) and 3 (CCR3) have been implicated in COPD, since the expression of these receptors on $\mathrm{T}$ cells infiltrated in COPD patients has been demonstrated. Il-8, growth related oncogene (GRO-alpha), and extractable nuclear antigen (ENA)-78 may be involved in the increased numbers of PMN in smokers' airspaces, whereas greater concentrations of macrophages, neutrophils, IL- $1 \beta$ and IL- 8 are elevated in the pulmonary microenvironment of smokers in a cigarette dose-dependent manner. ${ }^{35,36} \mathrm{IL}-8$ is a potent neutrophil chemoattractant found in elevated levels of this cytokine in induced sputum of COPD patients and was correlated with a high number of neutrophils. ${ }^{37,38}$ Concentrations of IL- 8 are even higher in emphysema patients, where there is a-1 antitrypsin deficiency. ${ }^{39}$

Inhibitory cytokines, including IL-10, transforming growth factor $\beta 1$ (TGF- $\beta 1$ ), IL-11, and the receptor antagonist of IL-1 are also delivered to limit the duration and extent of the inflammatory response in the lung of patients with COPD, but there is limited information. IL-10 is particularly useful as an inhibitor of various inflammatory processes, low levels of IL-10 positive cells in sputum of COPD patients have been reported. ${ }^{36}$

\section{Genetic polymorphisms associated with COPD}

As mentioned previously, COPD is characterized by chronic inflammation based on an abnormal inflammatory response. Studies found different polymorphisms in genes encoding inflammatory mediators that have been implicated in the pathogenesis of the disease, such as tumor necrosis factor (TNF), IL-8 and TGF $b$, and others. Regarding the TNF gene, as previously described, one SNP in the promoter region of the gene, which has been identified directly, affects the transcriptional regulation of the same. ${ }^{40}$ Studies show some relevance to the SNP308G/A TNF in the Asian populations but not in Caucasian populations; for example, Japanese and Taiwanese populations show an increased prevalence of COPD in relation to their respective control groups, but these results have 
not been confirmed in other populations. ${ }^{41}$ Recent studies have shown a relationship between metabolic alterations and changes in the levels of TNF- $\alpha$ in the systemic circulation of patients with COPD, where TNF- $\alpha$ is associated with accelerated metabolism and protein loss of skeletal muscle and adipose tissue. ${ }^{42,43}$ Moreover, IL- 8 is a chemokine which mediates the activation and migration of neutrophils from peripheral blood to tissue. This plays an important role in initiating the amplification of the inflammatory response. A transversion $(A \rightarrow G)$ at position -351 of the promoter of IL-8 has been positively associated with bronchiolitis reported, but inversely associated with bronchial asthma. ${ }^{44-46}$ There are many genetic association studies of polymorphisms in genes whose protein products are involved in the inflammatory process, although their participation in the disease is not clear. Table 1 summarizes the main findings in COPD and in asthma.

\section{Major inflammatory mediators and regulatory processes}

A number of polymorphisms in genes encoding key proteins in the inflammatory process are found in promoter regions, including IL4, IL6, IL 8 and TNF, to name a few, so that it is important to meet regulatory aspects of these genes and their relationship to the pathologies in question. IL4 is a glycoprotein of molecular weight approximately $15 \mathrm{kDa}$. Its expression is restricted to activated T cells, mast cells, basophils and eosinophils. The $I L-4$ was discovered as a cofactor in the proliferation of resting B cells stimulated with anti-IgM. ${ }^{68,69} \mathrm{IL}-4$ acts as a differentiation factor for B lymphocytes by regulating the IgG4 isotype switching to IgE and induces an increased expression of major histocompatibility complex class II (MHC II). It also promotes Th2 differentiation from Th0 cells, stimulates their growth and proliferation and inhibits the development of Th1 cells. ${ }^{70} I L-4$ is shown to be increased in bronchoalveolar lavage (BAL) fluid and serum of allergic patients. People with atopy have altered regulation of the production of $I L-4$ in response to bacterial antigens and dust mites. Furthermore, atopic patients have a higher number of $\mathrm{T}$ cells secreting $I L-4$ compared with normal subjects. It also increases the release of chemokines such as CCL11 and expression of adhesion molecules such as VCAM-1 on lung fibroblasts, thereby promoting swelling of the airway, and inhibits the apoptosis of eosinophils and Th2 lymphocytes by expression of the Bcl-2 protein. ${ }^{71}$ The findings and potential roles in COPD are still unknown, although there are some reports of increased serum levels in relation to the degree of smoking, but these findings were found in African population and not replicated in Mexican mestizo population. ${ }^{72}$

\section{Gene structure and regulation of expression of IL-4}

IL 4 gene consists of 4 exons and 3 introns, located on the long arm of chromosome 5 in cytogenetic bands q23-31; it has potential binding sites for several transcription factors with positive or negative regulatory sequences, depending on the action generated after transcription factor binding. Among the main factors that interact with positive regulatory sequences are POS-1 and POS-2, which need to be assembled and which need to interact with different transcription factors such as C/EBP- g, NFIL6, NF- IL6/3, Jun or NF-AT, depending on the cellular expression. ${ }^{73,74}$

\section{IL-6}

This is a pleiotropic cytokine that plays an important role in regulating the immune and inflammatory response. It is produced by $\mathrm{T}$ cells, monocytes, fibroblasts, endothelial cells and keratinocytes. It also stimulates B cell differentiation and antibody production in synergy with IL-3 in the development of megakaryocytes and platelet production. It induces the expression of hepatic acute phase protein and has been associated with impaired functional capacity, reduced the daily physical activity and general deterioration of the health status. ${ }^{29,75,76}$ Before the nomenclature of IL-6, it was known in a variety of names, such

Table 1. Main findings related to IL-4, IL-6, IL-8 and TNF in COPD and asthma

\begin{tabular}{|c|c|c|c|}
\hline Protein & COPD & Asthma & References \\
\hline $\mathbb{I L}-4$ & no studies & $\begin{array}{l}\text { SNP associated with allergic rhinitis, serum levels and } \\
\text { induced sputum } \uparrow \uparrow\end{array}$ & 47,48 \\
\hline $\mathbb{I L}-6$ & $\begin{array}{l}\text { IL-6 } 6 \uparrow \uparrow \text { in induced sputum, BAL, and exhaled air } \\
\text { concentration during exacerbations, SNPs associated with } \\
\text { COPD }\end{array}$ & $\begin{array}{l}\text { serum levels and BAL } \uparrow \uparrow \text { in patients with no } \\
\text { allergic asthma }\end{array}$ & $49-52,54-56$ \\
\hline $\mathbb{L L}-8$ & $\begin{array}{l}\text { serum levels and induced sputum } \uparrow \uparrow \text {, several SNPs } \\
\text { associated with COPD }\end{array}$ & $\begin{array}{l}\text { levels } \uparrow \uparrow \text { in BAL, in asthmatic patients with C. pneumoniae } \\
\text { infection }\end{array}$ & $37,38,57-59$ \\
\hline TNF- $a$ & $\begin{array}{l}\text { serum levels and induced sputum } \uparrow \uparrow, \text { SNPs associated with } \\
\text { COPD and clinic phenotypes }\end{array}$ & $\begin{array}{l}\uparrow \uparrow \text { miRNAs involved in TNF regulation, serum levels } \uparrow \uparrow \\
\text { in asthmatic patients without eosinophils }\end{array}$ & $31,41,60-67$ \\
\hline
\end{tabular}

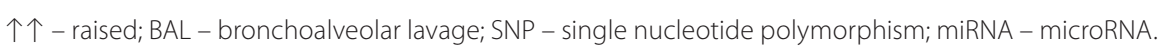


as IFN-b2, T cell replacement factor (TFR), B-cell differentiation factor (BCDF), B-cell stimulating factor, and hybridoma plasmacytoma growth (HPGF or IL-HP1). ${ }^{77-81}$ In relation to their association with disease, asthma patients showed elevated serum levels of IL- 6 and of bronchoalveolar lavage fluid, compared with nonsmokers with asthma whose results were as stable as non-asthmatics. ${ }^{49,50}$ Additionally, a study conducted by Neveu et al. in 2010 showed an increase in levels of IL- 6 and IL-13 in sputum from patients with allergic asthma; interestingly IL-1 b and TNF- $\alpha$ were not increased, which suggests an increase in IL- 6 independent of the degree of inflammation. ${ }^{51}$ In COPD, increased IL- 6 concentrations are found in induced sputum, bronchoalveolar lavage and concentrated exhaled air from COPD patients, particularly during exacerbations. ${ }^{52-54}$ IL-6 is also increased in plasma during exacerbations. ${ }^{55,56}$ There is genetic evidence regarding the involvement of certain $I L-6$ gene polymorphisms SNPs type involved in the increased production of the protein and its association with phenotypic traits, in both asthma and COPD. ${ }^{82-85}$

\section{Gene structure and regulation of expression of IL-6}

$I L-6$ gene is about $5 \mathrm{~kb}$ and consists of 4 exons and 6 introns, and is located on the short arm of chromosome 7 in the region p15-21. ${ }^{86,87}$ The expression control depends on several different stimuli and cellular mechanisms that can act individually or in concert to activate transcription. The first to be shown to induce the production of IL- 6 are the phorbol ester, IL- 1 and TNF- $\alpha .{ }^{88}$ Within the promoter region of IL6, there are regions of the target signal transduction. These targets include DNA binding regions which are specific for nuclear factors such as NFIL-6 (protein binding CCAAT elements), nuclear factor kappa light chain in B cells (NFkB), activator protein-1 (AP-1), protein binding cAMP response element (CREB), and glucocorticoid receptor (GR), these sequences can be found at $200 \mathrm{bp}$ upstream of the transcription start site. ${ }^{89,90}$

\section{IL-8}

IL-8 is a chemokine, a member of the CXC family, which is produced by macrophages, epithelial cells and fibroblasts in response to bacterial or viral stimulation or cellular stress response. It has been involved in the development of various biological processes such as repair, angiogenesis and inflammation..$^{91,92}$ Its main function is the chemotaxis of neutrophils and lymphocytes; it exerts its biological activity through 2 high affinity receptors designated as CXCR1 and CXCR2. Regarding the association of this chemokine with COPD, its function is still unknown, although studies of both genetic association and/or serum levels with this disease have been established. For example, Yamamoto et al. also reported elevated concentrations in sputum in COPD patients compared to different control groups. ${ }^{38}$ Consistent with this finding, Keatings et al. described elevated IL-8 in induced sputum of COPD patients compared to different control groups. ${ }^{37}$ Jeremy Hull et al. found polymorphism associated with bronchiolitis IL-8-251A in a family study conducted in the UK. ${ }^{57}$ Yet, there are no studies that prove the role of these polymorphisms in this disease. Recently, Alfredo de Diego et al. conducted a study in Valencia, Spain, in which the values determined in sputum of different cytokines, including IL-8, resulting in such high values. Additionally, cultured bronchial epithelial cells, which were stimulated with cigarette smoke extract, for the purpose of measuring mRNA levels, resulted in an increased amount of mRNA and TNF- $\alpha$, IL-8, which suggests that these molecules may increase in COPD, in response to the stimulus of cigarette smoke. ${ }^{58}$ Regarding the most important findings of IL-8 and asthma, the findings are limited; however, in 2010, Patel et al. found an increase in bronchoalveolar lavage IL8 mRNA in asthmatic patients with C. pneumoniae. ${ }^{59}$ No results are available on polymorphisms in $I L-8$ gene with asthma.

\section{Gene structure and regulation of expression of IL8}

IL-8 gene consists of 4 exons and 3 introns, with a total length of $5.25 \mathrm{kbp}$, and is located on the long arm of chromosome 4 in the region (q12-21)..$^{93}$ The 5 flanking region contains several $I L-8$ gene regulatory elements, e.g., binding sites for transcription factors such as NF-kB, NF-IL6, AP-1, AP-2, AP-3, interferon regulatory factor-1 (IRF-1) and glucocorticoid response elements (GRE). ${ }^{93}$ Transcriptional activation can occur after the stimulation with IL-l $\alpha$ IL-1 $\beta$, TNF- $\alpha$, bacterial endotoxin, reactive oxygen species and nitrogen intermediates. ${ }^{94} I L-8$ can also be regulated at a post-transcriptional level, because in the 3' flanking region contains a repeat motif ATTTA, which is responsible for mRNA destabilization of several different cytokines. ${ }^{95}$ TNF- $\alpha$ is the primary mediator of the immune response to gram-negative bacteria and other infectious organisms. The release of TNF $\alpha$ produced the local activation of vascular endothelium, with a release of nitric oxide, vasodilation and increased vascular permeability, leading to the recruitment of inflammatory cells, immunoglobulins and complement, causing the activation of $\mathrm{T}$ and $\mathrm{B}$ lymphocytes. It also increases adhesion and platelet activation. ${ }^{96}$ Tumor necrosis factor alpha is a critical molecule in the regulation of inflammation, inducing a cascade of other inflammatory cytokines, chemokines and growth factors. ${ }^{97}$ The results of several studies in vivo and in vitro indicate that the increased production of TNF- $\alpha$ leads to an increase in inflammation 
and pro-oxidative response. TNF- $\alpha$ mediates inflammation and is thought to play a key role in respiratory and systemic features of COPD. ${ }^{60}$ Jardim et al. found increased expression of the miRNAs involved in the regulation of TNF, IL-8 and COX2 in epithelial cells of asthmatic patients. ${ }^{61}$ In another study, Waserman et al. found an increase in serum levels of Th1-type cytokines, including TNF- $\alpha$, in asthmatic patients without eosinophilia. ${ }^{62} \mathrm{~A}$ result which correlates with these findings on this molecule has been described previously. With respect to TNF- $\alpha$ and its association with COPD in 2010, Tanni et al. conducted a study that showed high serum levels of TNF- $\alpha$ in patients with COPD and healthy chronic smokers compared with nonsmokers. ${ }^{63}$ In another study, Gan et al. found elevated levels of TNF- $\alpha$ in bronchoalveolar lavage and induced sputum of COPD patients compared to the control group. Genetic association studies of TNF in COPD show some significance for rs1800629 (position -308 G/A) in Asian populations, but not in Caucasian populations. ${ }^{41}$ However, these results are contradictory, because they could not be confirmed in other populations. In 2012, a study was conducted in the Taiwanese population, which identified TNF-863 (rs1800630) with an improvement in FEV1/ FVC and with increasing BMI. ${ }^{64}$ Another gene that affects the expression of TNF- $\alpha$ is lymphotoxin alpha gene $(L T A)$. The rs909253 $(\mathrm{G} \rightarrow \mathrm{A})$ in LTA has been implicated in gene regulation and reported associations with asthma and COPD. ${ }^{31,65,66}$ Elevated serum TNF- $\alpha$ levels have been associated with SNPs in LTA. ${ }^{67}$

\section{Structure and regulation of gene expression of $T N F$}

TNF gene was cloned in 1984 and mapped along with the major histocompatibility complex on chromosome 6 21.3, along with genes encoding LT-a and LT-b. ${ }^{98-100}$ The TNF gene consists of 4 exons and 3 introns, of which the last exon encodes over $80 \%$ of the secreted protein. ${ }^{101}$ The major regulatory gene elements of TNF are the elements of response to NFkB important factor involved in LPS conferred inducibility. However, many other factors may be involved in the selective activation and expression of TNF. The mRNAs of TNF and LT, like many other cytokines, have AU-rich sequences in the 3'UTR region of the mRNA, which decreases its stability. ${ }^{102}$ These sequences represent recognition sites for specific mRNA processing proteins. In 1988, Beutler et al. identified a ribonuclease that was isolated from mouse macrophages, which specifically destabilizes mRNA containing the sequence UUAUUUAU in the 3'UTR. ${ }^{103,104}$ Interestingly, LT mRNA lacks these AU regions. Additionally, TNF- $\alpha$ induces several proteins involved in inflammation, tissue repair, hematopoiesis, immune response and anti-tumor effects. Some of these genes encode proteins called "TNF resistance proteins" which may inhibit TNF cytotoxicity. ${ }^{105}$ Examples of these proteins include superoxide dismutase, protein A-20 zinc finger and the heat shock protein-70 (HSP70) ${ }^{106-108}$ In Table 2, one can observe some polymorphisms in genes encoding the aforementioned proteins and their involvement in the expression.

\section{Conclusions}

Asthma and COPD are lung diseases, which represent a major public health problem and our country is no exception. Both disease entities share a common mechanism to inflammation, which acts differently in both pathologies. In this regard, there are several studies that have explored the levels of proteins involved in inflammation, both systemically and locally. According to these results, we can see that there are mediators that are shared in both diseases, such as IL1 $\beta$, IL- 6 and TNF- $\alpha$, plus some others which differ, such as IL-13, IL-4, IL-5, and IL-8. For this reason, to understand the regulatory mechanisms that lead to the expression of these gene products as well as the research studies which analyze the genetic variations and their relationship with the phenotype expressed, it is vital to differentiate the genetic and molecular mechanism of both illnesses and to provide more effective treatment alternatives that contribute to the improvement of the patient.

Table 2. Polymorphisms in genes associated to inflammation and its biological implication

\begin{tabular}{|c|c|c|c|c|c|}
\hline Gene & Polymorphism & Position & Change & Biological implication & Reference \\
\hline \multirow{3}{*}{ TNF } & rs1800629 & -308 & $G \rightarrow A$ & increases transcription and protein levels & 109 \\
\hline & rs361525 & -238 & $\mathrm{G} \rightarrow \mathrm{A}$ & increases transcription & 110 \\
\hline & rs1800630 & -863 & $C \rightarrow A$ & decreased binding capacity of NFkB & 111 \\
\hline \multirow{2}{*}{ IL-4 } & rs2243250 & -589 & $C \rightarrow T$ & increases transcriptional activity & 112,113 \\
\hline & rs2070874 & -33 & $C \rightarrow T$ & increases the amount of protein & 114 \\
\hline \multirow{2}{*}{ IL-6 } & rs1800795 & -174 & $\mathrm{G} \rightarrow \mathrm{C}$ & increased plasma levels & 115 \\
\hline & $\mathrm{G} / \mathrm{G} / \mathrm{A}$ & $-174 /-572 /-597$ & GGG/A & haplotype associated with increased mRNA & 116 \\
\hline IL-8 & rs4073 & -251 & $A \rightarrow T$ & increases the protein expression up to 5 folds & 44,117 \\
\hline
\end{tabular}




\section{References}

1. Holgate ST, Polosa R. Treatment strategies for allergy and asthma. Nat Rev Immunol. 2008;8(3):218-230.

2. Kallal LE, Lukacs NW. The role of chemokines in virus-associated asthma exacerbations. Curr Allergy Asthma Rep. 2008;8(5):443-450.

3. Leong $A B$, Ramsey $C D$, Celedón JC. The challenge of asthma in minority populations. Clin Rev Allergy Immunol. 2012;43(1-2):156-183. doi:10.1007/s12016-011-8263-1.

4. Nelson HS. The importance of allergens in the development of asthma and the persistence of symptoms. Dis Mon. 2001;47(1):5-15.

5. Karjalainen J, Hulkkonen J, Nieminen MM, et al. Interleukin-10 gene promoter region polymorphism is associated with eosinophil count and circulating immunoglobulin E in adult asthma. Clin Exp Allergy. 2003;33(1):78-83.

6. Holgate ST, Davies DE, Powell RM, Howarth PH, Haitchi HM, Holloway JW. Local genetic and environmental factors in asthma disease pathogenesis: Chronicity and persistence mechanisms. Eur Respir J. 2007;29(4):793-803.

7. Holgate ST. Pathogenesis of asthma. Clin Exp Allergy. 2008;38(6):872-897.

8. Kearley J, Robinson DS, Lloyd CM. CD4+CD25+ regulatory T cells reverse established allergic airway inflammation and prevent airway remodeling. J Allergy Clin Immunol. 2008;122(3):617-624.

9. Robinson DS, Hamid Q, Ying S, et al. Predominant TH2-like bronchoalveolar T-lymphocyte population in atopic asthma. N Engl J Med. 1992;30;326(5):298-304

10. Foster PS, Martinez-Moczygemba M, Huston DP, Corry DB. Interleukins-4, -5, and -13: Emerging therapeutic targets in allergic disease. Pharmacol Ther. 2002;94(3):253-264.

11. Hamelmann E, Cieslewicz G, Schwarze J, et al. Anti-interleukin 5 but not anti-IgE prevents airway inflammation and airway hyperresponsiveness. Am J Respir Crit Care Med. 1999;160(3):934-941.

12. Kumar RK, Herbert C, Yang M, Koskinen AM, McKenzie AN, Foster PS. Role of interleukin-13 in eosinophil accumulation and airway remodelling in a mouse model of chronic asthma. Clin Exp Allergy. 2002;32(7):1104-1111.

13. Louten J, Boniface K, de Waal Malefyt R. Development and function of TH17 cells in health and disease. J Allergy Clin Immunol. 2009;123(5):1004-1111.

14. Grünig G, WarnockM, Wakil AE, et al. Requirement for IL-13 independently of IL-4 in experimental asthma. Science. 1998;282(5397):2261-2263.

15. Shim JJ, Dabbagh K, Ueki IF, et al. IL-13 induces mucin production by stimulating epidermal growth factor receptors and by activating neutrophils. Am J Physiol Lung Cell Mol Physiol. 2001;280(1):134-140.

16. Sidhu SS, Yuan S, Innes AL, et al. Roles of epithelial cell-derived periostin in TGF-beta activation, collagen production, and collagen ge elasticity in asthma. Proc Natl Acad SciU S A. 2010;107(32):14170-14175.

17. Takayama G, Arima K, Kanaji T, et al. Periostin: A novel component of subepithelial fibrosis of bronchial asthma downstream of IL-4 and IL-13 signals. J Allergy Clin Immunol. 2006;118(1):98-104

18. Williams CM, Galli SJ. Mast cells can amplify airway reactivity and features of chronic inflammation in an asthma model in mice. J Exp Med. 2000;192(3):455-462.

19. Yu M, Tsai M, Tam SY, Jones C, Zehnder J, Galli SJ. Mast cells can promote the development of multiple features of chronic asthma in mice. J Clin Invest. 2006;116(6):1633-1641.

20. Balzar S, Fajt ML, Comhair SA, et al. Mast cell phenotype, location, and activation in severe asthma. Data from the Severe Asthma Research Program. Am J Respir Crit Care Med. 2011;183(3):299-309.

21. Van Beijsterveldt CE, Boomsma DI. Genetics of parentally reported asthma, eczema and rhinitis in 5-yr-old twins. Eur Respir J. 2007:29(3):516-521.

22. Sleiman PM, Flory J, Imielinski M, et al. Variants of DENND1B associated with asthma in children. NEngl J Med. 2010;7;362(1):36-44.

23. Li X, Howard TD, Zheng SL, et al. Genome-wide association study of asthma identifies RAD50-IL13 and HLA-DR/DQ regions. J Allergy Clin Immunol. 2010;125(2):328-335.

24. Torgerson DG, Ampleford EJ, Chiu GY, et al. Meta-analysis of genomewide association studies of asthma in ethnically diverse North American populations. Nat Genet. 2011;43(9):887-892. doi:10.1038/ng.888.

25. Hoffjan S, Nicolae D, Ober C. Association studies for asthma and atopic diseases: A comprehensive review of the literature. Respir Res. 2003:4:14
26. Bals R, Hiemstra PS. Innate immunity in the lung: Now epithelial cells fight against respiratory pathogens. Eur Respir J. 2004;(2):327-333.

27. Global Strategy for the Diagnosis, Management and Prevention of COPD, Global Initiative for Chronic Obstructive Lung Disease (GOLD); 2014. Available from http://goldcopd.org/. Accessed June 5, 2015.

28. Donaldson GC, Seemungal TA, Patel IS, et al. Airway and systemic inflammation and decline in lung function in patients with COPD. Chest 2005;128(4):1995-2004.

29. Garrod R, Marshall J, Barley E, Fredericks S, Hagan G. The relationship between inflammatory markers and disability in chronic obstructive pulmonary disease (COPD). Prim Care Respir J. 2007;16(4):236-240.

30. Menezes AM, Lopez MV, Hallal PC, et al. Prevalence of smoking and incidence of initiation in the Latin American adult population: The PLATINO study. BMC Public Health. 2009;9:151.

31. Hogg JC, Chu F, Utokaparch S, et al. The nature of small-airway obstruction in chronic obstructive pulmonary disease. NEngl J Med. 2004;24;350(26):2645-2653.

32. Hogg JC, Senior RM. Chronic obstructive pulmonary disease - Part 2: Pathology and biochemistry of emphysema. Thorax. 2002;57(9):830-834.

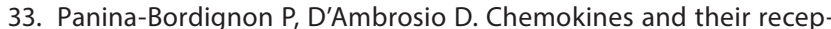
tors in asthma and chronic obstructive pulmonary disease. Curr Opin Pulm Med. 2003;9:104-110.

34. Saetta M, Mariani M, Panina-Bordignon P, et al. Increased expression of the chemokine receptor CXCR3 and its ligand CXCL10 in peripheral airways of smokers with chronic obstructive pulmonary disease. Am J Respir Crit Care Med. 2002;165:1404-1409.

35. Morrison D, Strieter RM, Donnelly SC, Burdick MD, Kunkel SL, MacNee W. Neutrophil chemokines in bronchoalveolar lavage fluid and leukocyte-conditioned medium from nonsmokers and smokers. Eur Respir J. 1998;12:1067-1072.

36. Kuschner WG, D'Alessandro A, Wong H, Blanc PD. Dose-dependent cigarette smoking-related inflammatory responses in healthy adults. Eur Respir J. 1996;9:1989-1994.

37. Keatings VM, Collins PD, Scott DM, Barnes PJ. Differences in interleukin- 8 and tumor necrosis factor-a in induced sputum from patients with chronic obstructive pulmonary disease or asthma. Am J Respir Crit Care Med. 1996;153:530-534.

38. Yamamoto C, Yoneda T, Yoshikawa M, et al. Airway inflammation in COPD assessed by sputum levels of interleukin-8. Chest. 1997;112:505-510.

39. Woolhouse IS, Bayley DL, Stockley RA. Sputum chemotactic activity in chronic obstructive pulmonary disease: Effect of alpha(I)-antitrypsin deficiency and the role of leukotriene $B(4)$ and interleukin 8 . Thorax. 2002;57:709-714.

40. Wilson AG, Symons JA, McDowell TL, McDevitt HO, Duff GW. Effects of a polymorphism in the human tumor necrosis factor alpha promoter on transcriptional activation. Proc Nat/Acad SciUSA. 1997;94:3195-3199.

41. Huang SL, Su CH, Chang SC. Tumor necrosis factor-alpha gene polymorphism in chronic bronchitis. Am J Respir Crit CareMed. 1997;156:1436-1439.

42. Argilés JM, López-Soriano J, Busquets S, López-Soriano FJ. Journey from cachexia to obesity by TNF. FASEB J. 1997;11:743-751.

43. Takabatake N, Sata M, Inoue S, et al. A novel polymorphism in secretory phospholipase A2-IID is associated with body weight loss in chronic obstructive pulmonary disease. Am J Respir Crit Care Med. 2005;172:1097-1104.

44. Hull J, Thomson A, Kwiatkowski D. Association of respiratory syncytial virus bronchiolitis with the interleukin 8 gene region in UK families. Thorax. 2000;55:1023-1027.

45. Heinzmann A, Ahlert I, Kurz T, Berner R, Deichmann KA. Association study suggests opposite effects of polymorphisms within IL8 on bronchial asthma and respiratory syncytial virus bronchiolitis. J Allergy Clin Immunol. 2004;114:671-676.

46. Shen L, Fahey JV, Hussey SB, Asin SN, Wira CR, Fanger MW. Synergy between IL-8 and GM-CSF in reproductive tract epithelial cell secretions promotes enhanced neutrophil chemotaxis. Cell Immunol. 2004;230:23-32.

47. Beyer $\mathrm{K}$, Nickel $\mathrm{R}$, Freidhoff $\mathrm{L}$, et al. Association and linkage of atopic dermatitis with chromosome 13q12-14 and 5q31-33 markers. J Invest Dermatol. 2000;115(5):906-908.

48. Kroegel C, Bakakos P. The inflammatory effector cell pattern in asthma and chronic obstructive pulmonary disease - What is it good for? Respiration. 2012;83(1):17-19. 
49. Yokoyama A, Kohno N, Sakai K, Kondo K, Hirasawa Y, Hiwada K. Circulating levels of soluble interleukin- 6 receptor in patients with bronchial asthma. Am J Respir Crit Care Med. 1997;156(5):1688-1691.

50. Tillie-Leblond I, Pugin J, Marquette $\mathrm{CH}$, et al. Balance between proinflammatory cytokines and their inhibitors in bronchial lavage from patients with status asthmaticus. Am J Respir Crit Care Med. 1999;159(2):487-494.

51. Neveu WA, Allard JL, Raymond DM, et al. Elevation of IL- 6 in the allergic asthmatic airway is independent of inflammation but associates with loss of central airway function. Respir Res. 2010;8:11-28.

52. Bhowmik A, Seemungal TA, Sapsford RJ, Wedzicha JA. Relation of sputum inflammatory markers to symptoms and lung function changes in COPD exacerbations. Thorax. 2000;55(2):114-120.

53. Song W, Zhao J, Li Z. Interleukin- 6 in bronchoalveolar lavage fluid from patients with COPD. Chin Med J. 2001;114:1140-1142.

54. Bucchioni E, Kharitonov SA, Allegra L, Barnes PJ. High levels of interleukin- 6 in the exhaled breath condensate of patients with COPD. Respir Med. 2003;97:1299-1302.

55. Wedzicha JA, Seemungal TA, MacCallum PK, et al. Acute exacerbations of chronic obstructive pulmonary disease are accompanied by elevations of plasma fibrinogen and serum IL- 6 levels. Thromb Haemost. 2000;84:210-215.

56. Debigare $\mathrm{R}$, Marquis $\mathrm{K}$, Cote $\mathrm{CH}$, et al. Catabolic-anabolic balance and muscle wasting in patients with COPD. Chest. 2003;124:83-89.

57. Hull J, Ackerman H, Isles K, et al. Unusual haplotypic structure of IL8, a susceptibility locus for a common respiratory virus. Am J Hum Genet. 2001; 69(2):413-419.

58. Damiá Ade D, Gimeno JC, Ferrer MJ, Fabregas ML, Folch PA, Paya JM. A study of the effect of proinflammatory cytokines on the epithelial cells of smokers, with or without COPD. Arch Bronconeumol. 2011;47(9):447-453.

59. Patel KK, Vicencio AG, Du Z, Tsirilakis K, Salva PS, Webley WC. Infectious Chlamydia pneumoniae is associated with elevated interleukin-8 and airway neutrophilia in children with refractory asthma. Pediatr Infect Dis J. 2010;29(12):1093-1098.

60. Mukhopadhyay S, Hoidal JR, Mukherjee TK. Role of TNF-alpha in pulmonary pathophysiology. Respir Res. 2006;11:7-125.

61. Jardim MJ, Dailey L, Silbajoris R, Diaz-Sanchez D. Distinct microRNA expression in human airway cells of asthmatic donors identifies a novel asthma-associated gene. Am J Respir Cell Mol Biol. 2012;47(4):536-542. doi:10.1165/rcmb.2011-01600C.

62. Waserman S, Nair P, Snider D, et al. Local and systemic immunological parameters associated with remission of asthma symptoms in children. Allergy Asthma Clin Immunol. 2012;8(1):16. [Epub ahead of print]

63. Tanni SE, Pelegrino NR, Angeleli AY, Correa C, Godoy I. Smoking status and tumor necrosis factor-alpha mediated systemic inflammation in COPD patients. J Inflamm. 2010;7:29.

64. Chen YC, Liu SF, Chin CH, et al. Association of tumor necrosis factoralpha-863C/A gene polymorphism with chronic obstructive pulmonary disease. Lung. 2010;188(4):339-347.

65. Messer G, Spengler U, Jung MC, Honold G, Blömer K, Pape GR. Polymorphic structure of the tumor necrosis factor (TNF) locus: An Ncol polymorphism in the first intron of the human TNF-beta gene correlates with a variant amino acid in position 26 and a reduced level of TNF-beta production. J Exp Med. 1991;1:173(1):209-219.

66. Migita O, Noguchi E, Koga M, et al. Haplotype analysis of a $100 \mathrm{~kb}$ region spanning TNF-LTA identifies a polymorphism in the LTA promoter region that is associated with atopic asthma susceptibility in Japan. Clin Exp Allergy. 2005;35(6):790-796.

67. Tomasdottir H, Hjartarson $\mathrm{H}$, Ricksten A, Wasslavik C, Bengtsson A, Ricksten SE. Tumor necrosis factor gene polymorphism is associated with enhanced systemic inflammatory response and increased cardiopulmonary morbidity after cardiac surgery. Anesth Analg. 2003;97(4):944-949.

68. Paul WE. Interleukin-4: A prototypic immunoregulatory lymphokine. Blood. 1991;1;77(9):1859-1870.

69. Paul WE. Interleukin 4: Signalling mechanisms and control of T cell differentiation. Ciba Found Symp. 1997;204:208-219.

70. Swain SL, Weinberg AD, English M, Huston G. IL-4 directs the development of Th2-like helper effectors. JImmunol. 1990;1;145(11):3796-3806.

71. Vandenbroeck K, Goris A. Cytokine gene polymorphisms in multifactorial diseases: Gateways to novel targets for immunotherapy? Trends Pharmacol Sci. 2003;24(6):284-289.
72. Merghani TH, Saeed A, Alawad A. Changes in plasma IL4, TNF-a and $\mathrm{CRP}$ in response to regular passive smoking at home among healthy school children in Khartoum. Sudan. Afr Health Sci. 2012;12(1): 41-47.

73. Li-Weber M, Krafft H, Krammer PH. A novel enhancer element in the human IL-4 promoter is suppressed by a position-independent silencer. J Immunol. 1993;151(3):1371-1382.

74. Li-Weber M, Salgame P, Hu C, Krammer PH. Characterization of constitutive and inducible transcription factors binding to the P2 NF-AT site in the human interleukin-4 promoter. Gene. 1997;188(2):253-260.

75. Schols AM, Buurman WA, Staal van den Brekel AJ, Dentener MA, Wouters EF. Evidence for a relation between metabolic derangements and increased levels of inflammatory mediators in a subgroup of patients with chronic obstructive pulmonary disease. Thorax. 1996;51(8):819-824.

76. de Torres JP, Cordoba-Lanus E, Lopez-Aguilar C, et al. C reactive protein levels and clinically important predictive outcomes in stable COPD patients. Eur Respir J. 2006;27(5):902-907.

77. Weissenbach J, Chernajovsky Y, Zeevi M, et al. Two interferon mRNAs in human fibroblasts: In vitro translation and Escherichia coli cloning studies. Proc Natl Acad Sci U S A. 1980;77(12):7152-7156.

78. Yoshizaki K, Nakagawa T, Kaieda T, Muraguchi A, Yamamura Y, Kishimoto T. Induction of proliferation and Ig production in human B leukemic cells by anti-immunoglobulins and T cell factors. J Immunol. 1982;128(3):1296-1301.

79. Okada M, Sakaguchi N, Yoshimura N, et al. B cell growth factors and $B$ cell differentiation factor from human Thybridomas. Two distinct kinds of B cell growth factor and their synergism in B cell proliferation. J Exp Med. 1983;157(2):583-590.

80. Hirano T, Taga T, Nakano N, et al. Purification to homogeneity and characterization of human B-cell differentiation factor (BCDF or BSFp-2). Proc Natl Acad Sci U S A. 1985;82(16):5490-5494.

81. Van Damme J, Opdenakker G, Simpson RJ, et al. Identification of the human $26-\mathrm{kD}$ protein, interferon beta 2 (IFN-beta 2), as a B cell hybridoma/plasmacytoma growth factor induced by interleukin 1 and tumor necrosis factor. J Exp Med. 1987;165(3):914-919.

82. Galicia JC, Tai H, Komatsu Y, Shimada Y, Akazawa K, Yoshie H. Polymorphisms in the IL-6 receptor (IL-6R) gene: Strong evidence that serum levels of soluble IL-6R are genetically influenced. Genes Immun. 2004;5(6):513-516.

83. Hawkins GA, Robinson MB, Hastie AT, et al. The IL6R variation Asp(358) Ala is a potential modifier of lung function in subjects with asthma. JAllergy Clin Immunol. 2012;130(2):510-515. doi:10.1016/j.jaci.2012.03.018

84. He JQ, Foreman MG, Shumansky K, et al. Associations of IL6 polymorphisms with lung function decline and COPD. Thorax. 2009;64(8):698-704.

85. Yanbaeva DG, Dentener MA, Spruit MA, et al. IL6 and CRP haplotypes are associated with COPD risk and systemic inflammation: A casecontrol study. BMC Med Genet. 2009;10:23.

86. Yasukawa K, Hirano T, Watanabe $Y$, et al. Structure and expression of human B cell stimulatory factor-2 (BSF-2/IL-6) gene. EMBO J. 1987;6(10):2939-2945.

87. Sehgal PB, Zilberstein A, Ruggieri RM, et al. Human chromosome 7 carries the beta 2 interferon gene. Proc Natl Acad Sci U S A. 1986;83(14):5219-5222.

88. Walther Z, May LT, Sehgal PB. Transcriptional regulation of the interferon-beta 2/B cell differentiation factor BSF-2/hepatocyte-stimulating factor gene in human fibroblasts by other cytokines. J Immunol. 1988;140(3):974-977.

89. Ray A, Sassone-Corsi P, Sehgal PB. A multiple cytokine- and second messenger-responsive element in the enhancer of the human interleukin-6 gene: Similarities with c-fos gene regulation. Mol Cell Biol. 1989;9(12):5537-5547.

90. Poli V, Mancini FP, Cortese R. IL-6DBP, a nuclear protein involved in interleukin- 6 signal transduction, defines a new family of leucine zipper proteins related to C/EBP. Cell. 1990;63(3):643-653.

91. Aihara $M$, Tsuchimoto $D$, Takizawa $H$, et al. Mechanisms involved in Helicobacter pylori-induced interleukin- 8 production by a gastric cancer cell line, MKN45. Infect Immun. 1997;65(8):3218-3224.

92. Khabar KS, Al-Zoghaibi F, Al-Ahdal MN, et al. The alpha chemokine, interleukin 8, inhibits the antiviral action of interferon alpha. J Exp Med. 1997;186(7):1077-1085.

93. Mukaida N, Shiroo M, Matsushima K. Genomic structure of the human monocyte-derived neutrophil chemotactic factor IL-8. J Immunol. 1989;143(4):1366-1371. 
94. Remick DG, Villarete L. Regulation of cytokine gene expression by reactive oxygen and reactive nitrogen intermediates. J Leukoc Biol. 1996;59(4):471-475.

95. Shaw G, Kamen R. Pillars article: A conserved AU sequence from the 3 untranslated region of GM-CSF mRNA mediates selective mRNA degradation. Cell. 1986;46:659-667. J Immunol. 2012;189(1):5-13.

96. Barnes PJ, Shapiro SD, Pauwels RA. Chronic obstructive pulmonary disease: Molecular and cellular mechanisms. Eur Respir J. 2003;22(4):672-688.

97. Wouters EF, Reynaert NL, Dentener MA, Vernooy JH. Systemic and local inflammation in asthma and chronic obstructive pulmonary disease: Is there a connection? Proc Am Thorac Soc. 2009;6(8): 638-647.

98. Pennica D, Nedwin GE, Hayflick JS, et al. Human tumour necrosis factor: Precursor structure, expression and homology to lymphotoxin. Nature. 1984;312(5996):724-729.

99. Gray PW, Aggarwal BB, Benton CV, et al. Cloning and expression of cDNA for human lymphotoxin, a lymphokine with tumour necrosis activity. Nature. 1984;312(5996):721-724.

100. Hajeer AH, Dababneh A, Makki RF, et al. Different gene loci within the HLA-DR and TNF regions are independently associated with susceptibility and severity in Spanish rheumatoid arthritis patients. Tissue Antigens. 2000;55(4):319-325.

101. Nedwin GE, Naylor SL, Sakaguchi AY, et al. Human lymphotoxin and tumor necrosis factor genes: Structure, homology and chromosomal localization. Nucleic Acids Res. 1985;13(17):6361-6373.

102. Caput D, Beutler B, Hartog K, Thayer R, Brown-Shimer S, Cerami A. Identification of a common nucleotide sequence in the 3 '-untranslated region of mRNA molecules specifying inflammatory mediators. Proc Natl Acad Sci U S A. 1986;83(6):1670-1674.

103. Beutler B. Application of transcriptional and posttranscriptional reporter constructs to the analysis of tumor necrosis factor gene regulation. Am J Med Sci. 1992;303(2):129-133.

104. Kruys V, Beutler B, Huez G. Translational control mediated by UArich sequences. Enzyme. 1990;44(1-4):193-202.

105. Fiers W, Beyaert R, Boone E, et al. TNF-induced intracellular signaling leading to gene induction or to cytotoxicity by necrosis or by apoptosis. J Inflamm. 1996;47(1-2):67-75.

106. Wong GH, Goeddel DV. Induction of manganous superoxide dismutase by tumor necrosis factor: Possible protective mechanism. Science. 1988;242(4880):941-944.
107. Opipari AW Jr, Hu HM, Yabkowitz R, Dixit VM. The A20 zinc finger protein protects cells from tumor necrosis factor cytotoxicity. J Biol Chem. 1992;267(18):12424-12427.

108. Jäättelä M, Wissing D. Heat-shock proteins protect cells from monocyte cytotoxicity: Possible mechanism of self-protection. J Exp Med. 1993;177(1):231-236.

109. Kroeger KM, Carville KS, Abraham LJ. The -308 tumor necrosis factor-alpha promoter polymorphism effects transcription. Mol Immunol. 1997;34(5):391-399.

110. Schulz S, Schagdarsurengin U, Suss T, Müller-Werdan U, Werdan K Gläser C. Relation between the tumor necrosis factor-alpha (TNFalpha) gene and protein expression, and clinical, biochemical, and genetic markers: Age, body mass index and uric acid are independent predictors for an elevated TNF-alpha plasma level in a complex risk model. Eur Cytokine Netw. 2004;15(2):105-111.

111. Udalova IA, Richardson A, Denys A, et al. Functional consequences of a polymorphism affecting NF-kappaB p50-p50 binding to the TNF promoter region. Mol Cell Biol. 2000;20(24):9113-9119.

112. Yannopoulos A, Nikiteas N, Chatzitheofylaktou A, Tsigris C. The (-590 $C / T)$ polymorphism in the interleukin-4 gene is associated with increased risk for early stages of corolectal adenocarcinoma. In Vivo. 2007;21(6):1031-1035.

113. Choi EH, Lee HJ, Yoo T, Chanock SJ. A common haplotype of interleukin-4 gene IL4 is associated with severe respiratory syncytial virus disease in Korean children. J Infect Dis. 2002;186(9):1207-1211.

114. Quirico-Santos T, Suppiah V, Heggarty S, Caetano R, Alves-Leon S, Vandenbroeck K. Study of polymorphisms in the interleukin-4 and IL-4 receptor genes in a population of Brazilian patients with multiple sclerosis. Arq Neuropsiquiatr. 2007;65(1):15-19.

115. Pereira DS, Garcia DM, Narciso FM, et al. Effects of $174 \mathrm{G} / \mathrm{C}$ polymorphism in the promoter region of the interleukin- 6 gene on plasma IL-6 levels and muscle strength in elderly women. Braz J Med Biol Res. 2011;44(2):123-129.

116. Gordon A, Kiss-Toth E, Stockley I, Eastell R, Wilkinson JM. Polymorphisms in the interleukin-1 receptor antagonist and interleukin-6 genes affect risk of osteolysis in patients with total hip arthroplasty. Arthritis Rheum. 2008;58(10):3157-3165.

117. Lee WP, Tai DI, Lan KH, Li AF, Hsu HC, Lin EJ. The-251T allele of the interleukin-8 promoter is associated with increased risk of gastric carcinoma featuring diffuse-type histopathology in Chinese population. Clin Cancer Res. 2005;11(18):6431-6441. 